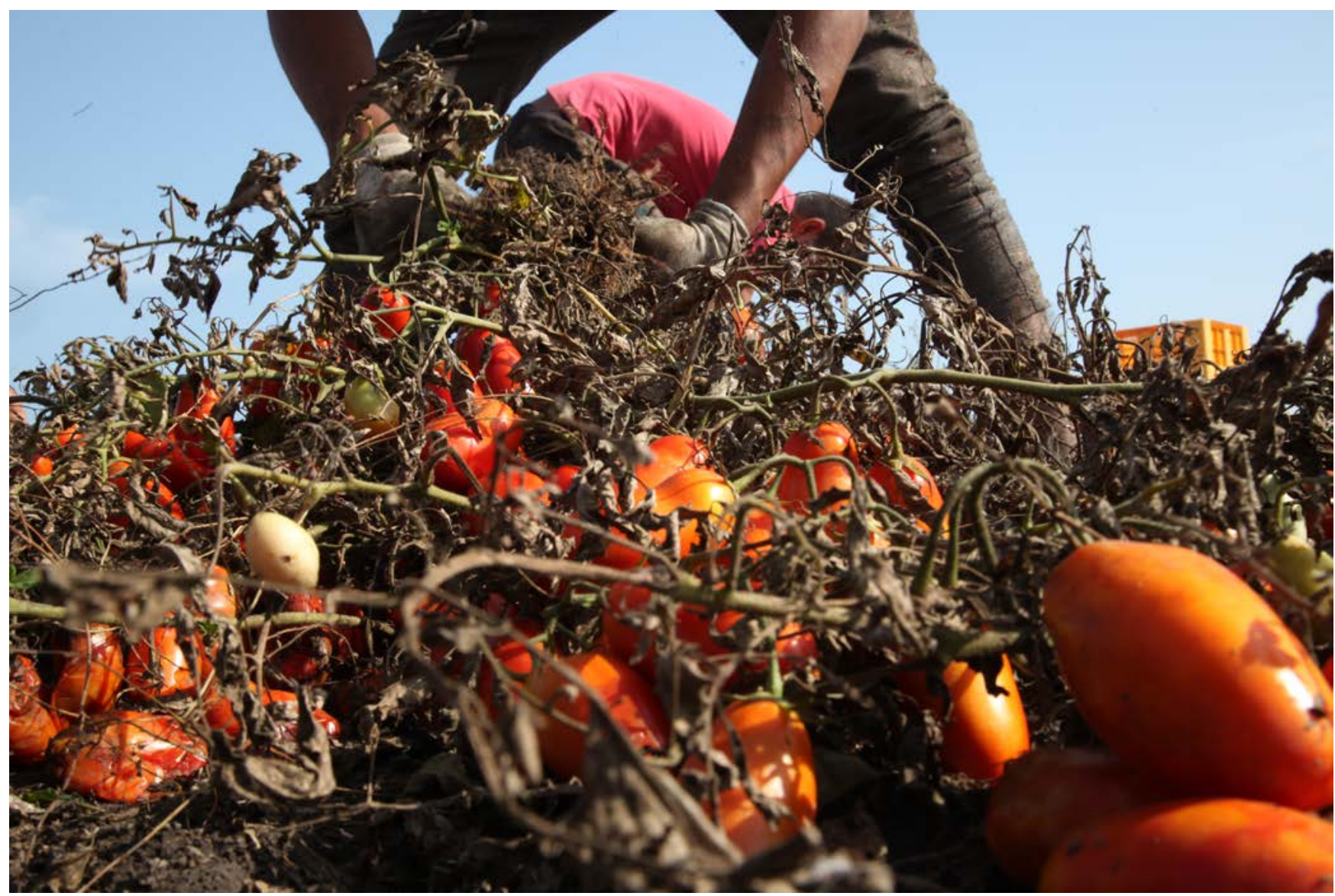

Workers on a tomato plantation in Italy. Credit: Mario Poeta/Terra!

\title{
HUMAN SUFFERING IN ITALY'S AGRICULTURAL VALUE CHAIN
}

Poverty is widespread among the small-scale farmers and workers who produce and process our food, in an industry worth billions of dollars. Oxfam's new campaign highlights the systemic inequality and human suffering in food supply chains - and shows how action by supermarkets, governments, small-scale farmers and workers could lead to a decent and dignified standard of living for millions of people.

This case study reveals endemic economic exploitation of farm workers in Italy who supply fruit and vegetables to supermarkets across Europe. It highlights the particular vulnerability of women and migrant workers, many of whom are recruited by gangmasters and forced to live and work in inhumane conditions. Wages are deducted in return for transport, food and accommodation. Workers express fear of sexual harassment, violence and exploitation.

It is one of a series of case studies to supplement the global campaign report, $\underline{\text { Ripe }}$ for Change, drawing attention to the plight of specific groups of small-scale farmers or workers in international food value chains and/or promoting successful alternative approaches. 


\section{INTRODUCTION}

Over the last 30 years, agriculture has developed new forms of production, but it still requires cheap labour. This is especially true in those European countries where agricultural labour is normally temporary, and requires workers to move from farm to farm according to seasonal farming demands. In this context, economic exploitation ${ }^{1}$ of workers to provide low-cost food for the retail sector is pervasive. In Europe, agriculture is one of the main sectors facing the scourge of informal or undeclared work and serious forms of worker exploitation. ${ }^{2}$

In Italy, the systematic denial of rights of women and men, especially migrant workers from Europe and Africa, underpins the production of seasonal fruits and vegetables such as fresh and canned tomatoes, oranges, strawberries, grapes, melons, watermelons and olives. These products make their way onto supermarket shelves across Italy and Europe. ${ }^{3}$

Although it is not easy to ascertain the number of foreign workers in Italian agriculture, the latest official figures show that in 2015 around 405,000 foreign people were regularly employed in this sector, ${ }^{4}$ making up $48 \%$ of the total workforce in agriculture. ${ }^{5}$ Women comprised about $27 \%$ of the agricultural labour force in Italy in $2015 .{ }^{6}$

However, the official statistics do not capture the agricultural work of 'irregular' workers - including Italians, regular migrants and irregular migrants ${ }^{7}$ - who are employed without an official contract, and whose employers fail to declare the employment relationship to the authorities, to avoid paying taxes and social security. This lack of regulation is a structural component of the agricultural sector in Italy - especially in the south, which is characterized by the presence of small and medium-sized farms that are difficult to monitor.

Estimates from Placido Rizzotto Observatory show that in 2015, around 430,000 workers were somehow irregularly employed in agriculture in Italy. ${ }^{8}$ Of these, $80 \%$ were foreign workers and about 100,000 were identified as being at high risk. Women farm workers comprised $42 \%$ of irregular farm workers, and women are usually overrepresented in unpaid and seasonal work. Evidence also suggests that women are often paid less than men for the same work. ${ }^{9}$

Workers' legal and social vulnerability results in many forms of human rights violations. Farm workers in Italian agriculture can work 10-12 hours a day, breathing in toxic pesticides and enduring the summer heat and the winter cold, for pay that is considerably below the legal minimum wage. Most live in degrading and unsanitary conditions, either in isolated outbuildings on the farms, or in city slums many miles from the fields where they work. ${ }^{10}$ Women migrant workers report sexual harassment and physical violence.

A system known as 'caporalato' exacerbates the suffering of female and male workers. Through an elaborately constructed gangmaster system, powerful bosses and their teams use intimidation, exploitation and violence to recruit and organize the labour force.

All too often, large retailers also impose low-cost operations on producers which have knock-on effects on workers. For example, supermarkets run 'double-race' online auctions to incentivize processing companies to offer the lowest possible prices, which reverberates all the way down the supply chain (see Box 1 ). 


\section{WOMEN AND MIGRANTS ARE AMONG THE MOST VULNERABLE WORKERS}

The agricultural sector in Italy, especially in the south, has been severely affected by corporate concentration - i.e. the expansion of retailers, processors and distributors by swallowing up smaller players to increase their market share and power - both 'upstream' (e.g. inputs and services) and 'downstream' (e.g. processors and retailers further along the supply chain) of farming. In this context, under growing pressure from large production and distribution systems, many local agricultural producers cut their costs by turning to employment of a low-paid labour force. This results in the exploitation of the more vulnerable categories of daily-waged farm workers: namely women and migrants.

'Irregular' or undocumented migrants, mostly from Africa, provide a significant and growing pool of cheap and vulnerable labour in Italy. Being in Italy without regular immigration status (i.e. without a valid visa and work permit) is a criminal offence, and the lack of alternative opportunities forces many migrants to accept inhumane working and living conditions.

However, holding a valid residence permit does not guarantee labour rights protection - regular migrants also very often experience poor working conditions and extremely low pay. This is the case for a growing number of workers coming from new EU member countries, especially from Romania and Bulgaria, despite their regular (by definition) right to migrate and work within the EU.

There are two principal reasons for the increasing recruitment of these workers. First, by employing EU citizens, suppliers can avoid legal sanctions linked to the facilitation of illegal migration. Second, recently arrived workers are 'cheaper' than those who have been working in Italy for a long time, who have developed solid relationships with the local people and are mostly unionized. This is seen for example in the experiences of Romanian workers employed in agriculture in Sicily, who suffer harsher conditions than the more established Tunisian workers. ${ }^{11}$

Women, both Italian and foreign, are increasingly employed in seasonal agricultural work due to their perceived ability to handle delicate fruits such as strawberries and grapes. ${ }^{12}$ Their vulnerability results from the growing pressure in the sector to reduce costs, and women's need to financially sustain themselves and their families. Women workers face a combination of excessive overtime, harsh working and living conditions, withholding of wages, intimidation, threats and physical and sexual violence. ${ }^{13}$ Evidence suggests that women are usually paid 20-30\% less than men for the same work and are much more likely to be subject to blackmail, in a system where gaining and maintaining employment may entail sexual exploitation and harassment. ${ }^{14}$

Estimates by the Italian trade union FLAI-CGIL show that of the 430,000 workers irregularly employed in the Italian agricultural sector in $2015,42 \%$ were women. ${ }^{15}$ Data on the most affected regions indicates the prevalence of exploitation of women farm workers. Of the 45,000 women employed in Campania, contractual obligations were not respected in $80 \%$ of cases. ${ }^{16}$ Placido Rizzotto Observatory has identified that about 40,000 Italian and 18,000 migrant women have experienced

'Strawberries are extremely delicate and can easily become unsellable. Only women can pick them, working in greenhouses exceeding 40 degrees.'

Woman farm worker, Apulia. Source: Oxfam interviews, June 2017

'In the last two years, it has been extremely difficult to find an alternative, decent job. That is why I cannot think of reporting abuses to the authorities.'

Woman farm worker, Sicily. Source: Oxfam interviews, June 2017 
some form of economic exploitation in the Apulia region's agriculture sector, as have 5,000 Italian women and 2,700 migrant women in the province of Ragusa in Sicily. ${ }^{17}$

However, this data may underestimate the phenomenon. Given the lack of alternatives for many of these workers - together with the fear of repercussions and isolation many women do not report their experiences to the police.

Many women farm workers also face physical and non-physical sexual harassment, with threats to their children and family. Multiple cases of sexual assault and labour exploitation have been documented in the province of Ragusa, in Sicily, Europe's third largest producer of vegetables, where more than 2,000 female Romanian farm workers are subject to forced labour, suffering horrendous abuses. ${ }^{18}$ This has been linked to the disproportionately high number of abortions among Romanian women in the city: 119 in 2015 and 111 in 2016, equal to $20 \%$ of total abortions in the entire province. ${ }^{19}$ 


\section{WORKERS EXPERIENCE MULTIPLE LABOUR AND HUMAN RIGHTS VIOLATIONS}

'We were working from 6.00 in the morning to 6.00 in the evening, every day of the week, for $€ 25$ a day. We could just take 10-minute breaks for eating.'

Aversa, a 24-year-old male agricultural worker from Mali. Source: Oxfam interviews, July 2017

Many studies, reports and investigations carried out in Italy in recent years provide evidence about the different ways in which the rights of people working in the agricultural value chain are denied. These include:

- Wages well below the legal minimum as indicated by national collective agreements.

- The systematic violation of working-time rules, including failure to grant daily breaks, weekly rest periods and annual holidays.

- Unsafe and unhealthy working conditions.

- Substandard housing and living conditions, with workers forced to live in dilapidated hovels, tent cities without heating, or shipping containers.

In my payslip, the wage was €46 per day. But l've never seen that money. I only received €28 per day.'

Woman farm worker, Campania

- Excessive control of workers' lives by employers, including the use of surveillance, or other abuses that exploit workers' legal and social vulnerability.

- Physical and verbal sexual harassment or violence faced by women workers, as discussed above.

Exploited agricultural workers usually work eight to 12 hours a day, often seven days a week and without breaks, and are usually seriously underpaid. They can earn a wage of $€ 22-30$ per day $-50 \%$ lower than the legal minimum (€47 in 2017). For many, wages are paid through the illegal practice of 'piecework', with workers earning around $€ 3-4$ for every $300 \mathrm{~kg}$ of tomatoes picked. ${ }^{20}$

Non-payment of wages, as well as delayed and/or partial payment, is also very common. As reported by FLAI-CGIL, payslips of agricultural workers - even those who are formally employed, with a regular and full-time contract - often only show a few days of work, with others arbitrarily deducted as 'taxes'. ${ }^{21}$

Working conditions in the plastic greenhouses are extremely hard. Workers endure sweltering heat during the summer and low temperatures in the winter, all the while breathing in pesticides and herbicides that are harmful to health. Toilet or meal breaks are not guaranteed, and in any case must be very short.

Seasonal agricultural workers, especially migrants, also have to suffer appalling housing conditions. Workers usually live in slums, or in disused buildings or factories in remote rural areas, without running water, electricity or heating. According to estimates by Placido Rizzotto Observatory, $60 \%$ of irregular farm workers do not have access to clean water or sanitation services. ${ }^{22}$

'They treat us like beasts. They control how many times we go to the toilet and tell us to come back soon. If you refuse to work on Sunday they threaten to fire you.'

Woman farm worker, Campania 


\section{THE 'CAPORALATO' SYSTEM: FROM ILLEGAL RECRUITMENT TO THE COMPLETE CONTROL OF WORKERS}

A distinct feature of labour exploitation in seasonal agriculture in Italy is the widespread unlawful gangmaster system known as 'caporalato'. ${ }^{23}$ This is defined as the act of conducting an organized activity of intermediation, recruiting manpower or organizing a workforce, and is characterized by use of violence, threats and intimidation.

Caporalato is not a new system in Italy - it has regulated the seasonal labour market in agriculture across the country for many years. However, in recent years the new figure of 'caporale' has emerged: an individual who goes beyond the role of recruiter on behalf of local producers. The caporale strictly controls and manages workers' daily lives - including travel to and from the farm, housing, meals, their social contacts as well as payroll criteria, working time and wages.

The caporalato system is widely used in many seasonal fruit and vegetable value chains, such as tomatoes, oranges, strawberries and wine grapes. In 2015, inspections by FLAI-CGIL of 8,862 agricultural companies in more than 80 territories found 6,153 irregular workers and 713 cases of caporalato. ${ }^{24}$

Farmers claim that this system is the only way they have to put together efficient crews of workers because the employment centres are ineffective and the workers themselves use members of their community to find jobs. The caporalato system flourishes in certain conditions, including where there is: ${ }^{25}$

- High demand for a short-term and very flexible labour force, especially during seasonal harvesting of fruit and vegetables.

- Lack of integration and high fragmentation within the production system.

- Workplaces which are very isolated (in remote rural areas) or where conditions can be extreme (e.g. greenhouses).

- Weak producer organizations (POs) that do not effectively represent local producers' interests.

- Presence of criminal organizations.

- Lack of official recruitment services.

Through caporalato, gangmasters arbitrarily decide who can be part of their teams. They take advantage of workers' fragile socio-economic status and illegally profit by directly deducting money from workers' daily wages. For each day of work, some workers must pay the caporale a fee of $€ 5$ for transportation to the farm; workers may be also forced to buy food and water from the caporale at a higher price than it would cost at the local supermarket (e.g. $€ 1.50$ for $50 \mathrm{ml}$ water and $€ 3.50$ for a sandwich). At the end of the day, a sum up to $€ 10$ per worker - one-third of a worker's daily wage could be illicitly earned by the caporale and his or her team. ${ }^{26}$ Estimates by Placido Rizzotto Observatory, based on a monthly tomato harvest season, indicate that a team of caporali can make up to $€ 225,000$ per month. ${ }^{27}$ 
During the high season, hundreds of buses travel miles on poor roads to transfer workers from cities to the greenhouses. The caporali collect workers at the main roundabouts and squares, often leaving at around $3 \mathrm{a} . \mathrm{m}$. to reach the fields two hours or more later. At the end of the day, the bus drives the workers home again. Return trips of up to five hours are not counted in the working hours. ${ }^{28}$

In the last 10 years, the growing number of foreign/migrant seasonal workers in Italian agriculture has increased the demand for foreign caporali - who might be subordinated to Italian caporali - to facilitate communication with workers. In many cases, this person is the only point of contact for foreign/migrant workers, especially those without a legal permit to stay in Italy and who are therefore vulnerable to blackmail.

Although the caporalato system is characterized by machismo, the recruitment of 'With the agency, you will work not more than one month. With us, [you will get work for] at least six or eight months. It is up to you, what do you want?'

'Ok, let me go to the agency and stop the contract. l'll work for you.'

Intercepted dialogue between a female caporale and a woman farm worker.

women farm workers, especially Italians, is increasingly managed by women, as

evidenced by the number of women recently arrested and accused of being caporali. ${ }^{29}$ That may be because female caporali are more successful at convincing other women to accept specific conditions. 


\section{Box 1: Labour exploitation in Italy's tomato sector}

Tomatoes from Italy are exported all over the world. Italy is currently the second largest producer of processed tomato products worldwide and accounts for $50 \%$ of the EU's overall production. ${ }^{30}$ As reported by the Italian ANICAV (the National Industry Association for canned food), estimated sales of Italian tomatoes in 2015 amounted to around $€ 3 \mathrm{bn}$, with production at $5.5 \mathrm{~m}$ tonnes. ${ }^{31}$ Only about $40 \%$ of processed tomato products are marketed domestically, and the rest are sold worldwide.

These huge profits hide the enormous social and labour costs associated with this sector; in particular, the intensive labour exploitation and modern slavery-like conditions that make thousands of farm workers' lives a daily hell.

\section{Inhumane conditions for migrant workers}

In the last five years, dangerous working conditions faced by migrant workers who pick tomatoes bought by thousands of consumers every week in the major UK and European supermarkets have been reported in the international media. This began in July 2015, with the death of a Sudanese immigrant who suffered a heart attack while working in the fields of Nardó in southern Italy. ${ }^{32}$ The case helped to highlight the inhumane conditions suffered by thousands of tomato pickers working in the fierce summer heat in a region where some harvesting is still done by hand. Cases include people working for 12 hours a day, seven days a week, without breaks and for minimal pay. Non-payment of wages as well as delayed and/or partial payment are also very common. ${ }^{33}$

\section{Weak producer organizations}

The 'caporalato' gangmaster system is certainly part of the problem. However, one of the major structural distortions in the southern Italian tomato value chain is the ineffectiveness of producer organizations (POs), which have failed to prevent a few large, powerful retailers from squeezing production costs. As they are too small and located further from the field, POs have failed to negotiate secure purchasing prices, instead allowing them to depend on external factors such as the weather or the quality of the harvest. In this context, prices are very prone to fluctuations and fostering fairer value chains for farm workers is extremely difficult.

\section{Prices squeezed by double-race auctions}

Another important factor in this fragmented supply chain is the crucial role played by a few large retailers in perpetrating unfair practices that make farmers more vulnerable to price squeezes - and farm workers more likely to be exploited. One example of this is the use of 'double-race' online auctions by some retailers to set the price of raw materials/processed products. Supermarkets communicate by email a 'first-race' auction, well before the harvesting season, in order to receive processing companies' first price for a certain quantity of produce. After approximately 20 days, a second round is opened on the basis of the lowest bid received. This is again a downward auction that within a couple of hours will reward the lowest bid. This mechanism strongly affects the entire value chain, both because of the speed with which it takes place and because companies are forced to agree sales well before production quantities and costs have been determined. Having pre-sold at very low prices, processing companies therefore have to negotiate the lowest possible prices with producers, who must in turn make savings by hiring the cheapest possible labour or breaking their contractual obligations to farm workers. ${ }^{34}$ 


\section{ADDRESSING THE ROOT CAUSES OF LABOUR EXPLOITATION: PROGRESS AND RECOMMENDATIONS}

In October 2016, Italy took a crucial step to crack down on the widespread mistreatment of farm workers, by approving a new law against labour exploitation and caporalato. ${ }^{35}$ This legislation introduces innovative measures to eradicate the phenomenon, including sanctions on employers, land requisition, enhanced protection for victims, organized labour inspections and an integrated approach to punishing and ending labour exploitation. The law has substantially amended the Italian Penal Code and extended the responsibility of the employer who 'exploits workers by taking advantage of their situation of need or want'. ${ }^{36}$ This means labour exploitation can be punished even in the absence of illicit brokering in recruiting workers.

The new law positively contributes to the identification of cases of worker exploitation and can act as an effective deterrent. However, considering the scale of the caporalato phenomenon, the law only partially addresses the problem. Because it is based on repressive measures that can be applied only after a case occurs and has been verified, it requires huge inspection efforts and relies on the willingness of workers to denounce their exploiters.

More specifically, the law fails to promote a 'supply chain approach' aimed at increasing the transparency of the whole agricultural value chain as a means to fight caporalato and labour exploitation. What is needed is an integrated approach that addresses the root causes of labour exploitation in Italy's agricultural value chain. Currently this is a long, highly fragmented, ungoverned and opaque supply chain that involves many different actors and makes it impossible to reveal every place where labour exploitation hides.

In a long supply chain, each actor has to earn money. All too often, large retailers impose low-cost operations on producers which have knock-on effects on workers (see Box 1). Consumers are not able to know the history of a product and its path from the field to their table, or to assess products' social and environmental credentials.

A transparent supply chain, where all the steps are clearly traced, increases the responsibility of companies and suppliers along the whole value chain. This makes the exploitation of labour less economically viable because it can be more easily controlled by both authorities and consumers themselves.

Oxfam's new campaign aims to address human suffering in food supply chains. We hope that:

- Consumers will find it unacceptable to be sold food that is produced with human suffering, and will demand change.

- Governments will re-establish and enforce vital protections for small-scale farmers and workers, and rein in the abuse of power by supermarkets and food suppliers.

- Small-scale farmers and workers will be empowered to negotiate a fairer deal, and women among them will be firmly established at the negotiating table, with their rights respected. 
- Supermarkets and their suppliers will change their core business models, to share more power and distribute more revenues to the women and men that supply them.

In Italy, this means that the Italian government should:

- Introduce and implement binding legislation to ban unfair trading practices that penalize small-scale farmers and exploit agricultural workers. In this regard, Oxfam welcomes the recent agreement between the Italian Ministry of Agriculture and some large-scale Italian distributors to stop double-race auctions.

- Introduce minimum producer prices or other price-support mechanisms for smallscale farmers, to ensure that purchase prices cover the cost of sustainable production.

- Ensure that legal regulations and enforcement mechanisms are in place to oversee fair contractual obligations between suppliers and supermarkets or other institutional buyers.

- Encourage greater traceability and transparency, by requiring suppliers to disclose and make accessible the list of suppliers and firms in their supply chain.

- Introduce a clear labelling system that tells the consumer about a product's provenance as well as its individual suppliers (e.g. who they are, how many steps along the supply chain).

- Address the question of increasing safe and legal routes for migrants, for example by granting temporary work permits to meet the workforce needs of the agriculture supply chain, and prevent the exploitation of migrant workers.

Supermarkets should:

- Radically improve transparency by disclosing information about their suppliers and rewarding those that demonstrate a high level of transparency and are fully committed to upholding workers' and women's rights.

- Make a commitment to eliminate unfair trading practices through setting appropriate pricing that considers sustainable production costs; ensuring long-term contracts and reasonable payment terms for suppliers; and placing transparent, secure and predictable orders.

- Close the gap between the prevailing and a living wage for farmers and workers by ensuring that there is enough value at production level for women and men to live a decent life, and factor living wage and income benchmarks into price negotiations with suppliers.

- Exercise preferential sourcing from suppliers that guarantee a living income for their employees or that have more equitable business structures, and provide prominent shelf space for their products. Supermarkets should place a focus on sourcing from cooperative groups or women's collective enterprises that explicitly aim to share value with farmers or employees.

Through its new campaign, Oxfam is calling for an end to human suffering in food supply chains, and promoting alternative business models that give the people behind the products a fair share of the value. To find out more about the campaign, and to read the full set of recommendations, see Ripe for Change. 
1 For the purposes of this study, economic exploitation is used interchangeably with the failure to respect labour rights. Note that the legal basis for international human and labour rights obligations are found in the Universal Declaration of Human Rights (1948); the International Covenant on Economic Social and Cultural Rights (1966) and the International Covenant on Civil and Political Rights (1966). Other relevant international labour standards can be found in the eight fundamental Conventions of the International Labour Organization, which can be accessed here: http://www.ilo.org/global/standards/introduction-to-international-labour-standards/conventions-and-recommendations/lang--en/index.htm

2 Eurispes - UILA, \#sottoterra - "Indagine sul lavoro sommerso in agricoltura" Eurispes Italian Union of Agricultural Workers, Rome 2014.

3 Note that the top export markets for fresh Italian tomatoes by value include Germany, Austria, the UK, Switzerland and France; for processed tomato paste top export markets by value include Germany, France, the UK, Libya and Nigeria; top export markets for oranges include Germany, Switzerland, Austria, France and Sweden; top export markets for strawberries include Germany, Austria, Switzerland and the UK. Based on data from FAO Stats, using most recently available figures (2013).

4 CREA. (2015). Annuario dell'Agricoltura Italiana 2015. Consiglio per la Ricerca in agricoltura e l'analisi dell'Economia Agraria (CREA). Rome. http://www.reterurale.it/annuario2015

5 According to the Italian National Institute for Statistics (Istat), 843,000 people were employed in agriculture in 2015. https://www.istat.it/it/agricoltura

6 Ibid.

7 The category 'irregular migrants' is very broad. It includes: individuals who arrived in Italy 'irregularly', who are often referred to in Italian using the derogatory term 'clandestine' migrants; those who arrived in Italy regularly but then became irregular, for example by overstaying their visas; and rejected asylum seekers and others who have sought international protection and whose claims have been dismissed. 'Regular migrants' generally includes EU nationals, as well as non-EU nationals who are granted residence permits for reasons other than work (including family reunification, study, health reasons, etc.). Nonnationals with a regular migration status also include refugees.

8 Federazione Lavoratori AgroIndustria - Confederazione Generale Italiana del Lavoro FLAICGIL. Observatory Placido Rizzotto, 2017. https://www.flai.it/osservatoriopr/

9 Federazione Lavoratori Agrolndustria - Confederazione Generale Italiana del Lavoro FLAICGIL. Observatory Placido Rizzotto. (2016). III Rapporto Agromafie e Caporalato. ISBN: 978-88-230-2015-3. http://www.ediesseonline.it/catalogo/rapporti/agromafie-e-caporalatoterzo-rapporto

10 Ibid.

11 According to Oxfam's interviews with FLAI-CGIL trade union in Ragusa, Sicily, June 2017.

12 CREA. (2017). Le Donne in Agricoltura. Consiglio per la Ricerca in agricoltura e l'analisi dell'Economia Agraria (CREA). Rome. http://www.crea.gov.it/wpcontent/uploads/2017/03/REPORT-donne-in-agricoltura.pdf

13 L. Palumbo and A. Sciurba. (2015). Vulnerability to Forced Labour and Trafficking: The case of Romanian women in the agricultural sector in Sicily. Anti-Trafficking Review, issue 5, pp. 89-108. http://www.antitraffickingreview.org/index.php/atrjournal/article/view/136/140

14 Federazione Lavoratori Agrolndustria - Confederazione Generale Italiana del Lavoro FLAICGIL. Observatory Placido Rizzotto. (2016). III Rapporto Agromafie e Caporalato. Op cit.

15 Federazione Lavoratori Agrolndustria - Confederazione Generale Italiana del Lavoro FLAICGIL. Observatory Placido Rizzotto, 2017. Op. cit.

16 Federazione Lavoratori Agrolndustria - Confederazione Generale Italiana del Lavoro FLAICGIL. Observatory Placido Rizzotto. (2016). III Rapporto Agromafie e Caporalato. Op. cit.

17 Ibid. 
18 L. Tondo and A. Kelly. (2017,14th March). Sexual abuse \& slave-like conditions allegedly widespread for Romanian farmworkers in Sicilian greenhouses. The Observer (UK). https://www.business-humanrights.org/ja/node/153698

According to the ILO Forced Labour Convention, 1930 (No. 29), forced or compulsory labour is defined as 'all work or service which is exacted from any person under the threat of a penalty and for which the person has not offered himself or herself voluntarily'. As the ILO notes, 'it refers to situations in which persons are coerced to work through the use of violence or intimidation, or by more subtle means such as manipulated debt, retention of identity papers or threats of denunciation to immigration authorities.' See: http://www.ilo.org/global/topics/forcedlabour/definition/lang--en/index.htm

19 L'Espresso. (2017, 5 June). Sfruttamento, stupri e aborti: le braccianti rumene in Sicilia vivono ancora come schiave. http://espresso.repubblica.it/inchieste/2017/ 06/30/news/sfruttamento-stupri-e-aborti-le-braccianti-rumene-in-sicilia-continuano-avivere-come-schiave-1.305380

20 \#FilieraSporca. (2016). Spolpati. La crisi dell'industria del Pomodoro. Tra sfruttamento e insostenibilità. Third campaign report. http://www.filierasporca.org/wpcontent/uploads/2016/11/Terzo-Rapporto-Filierasporca WEB1.pdf

21 Federazione Lavoratori Agrolndustria - Confederazione Generale Italiana del Lavoro FLAI-CGIL. Observatory Placido Rizzotto. (2016). III Rapporto Agromafie e Caporalato. Op. cit.

22 Federazione Lavoratori Agrolndustria - Confederazione Generale Italiana del Lavoro FLAI-CGIL. Observatory Placido Rizzotto, 2017. Op. cit.

23 'Caporalato' (literally 'corporals') is the term used to describe the gangmaster system, usually headed by an individual 'caporale'; members are known as 'caporali'.

24 Federazione Lavoratori Agrolndustria - Confederazione Generale Italiana del Lavoro FLAI-CGIL. Observatory Placido Rizzotto, 2017. Op. cit.

25 \#FilieraSporca. (2016). La raccolta dei rifugiati: Trasparenza di filiera e responsabilità sociale delle aziende. Second campaign report. http://www.filierasporca.org/2016/wpcontent/uploads/2016/06/filierasporca 2016.pdf

26 L'Espresso. (2016, 13 May) Yvan Sagnet: "Il caporalato e le nuove forme di schiavitù". http://espresso.repubblica.it/attualita/2016/05/10/news/yvan-sagnet-il-caporalato-e-i-nuovi-schiavi-1.264704

27 Federazione Lavoratori Agrolndustria - Confederazione Generale Italiana del Lavoro FLAI-CGIL. Observatory Placido Rizzotto, 2017. Op. cit.

28 Amnesty International. (2012). Exploited Labour: Migrant workers in Italy's Agricultural Sector. https://www.amnestyusa.org/files/exploited labour. italy migrants report web.pdf

29 Corriere della sera. (2017). Il Caporalato ora è femmina. Le consorterie delle donne aguzzine. http://corrieredelmezzogiorno.corriere.it/bari/cronaca/17 giugno 22/caporalato-ora-femmina-4b110d74-5782-11e7-ab96-89044b88698d.shtml

30 Istituto di Servizi per il Mercato Agricolo Alimentare - ISMEA. "I numeri della filiera del pomodoro da industria", June 2017.

31 Associazione Nazionale Industriali Conserve Alimentari Vegetali - ANICAV. 2017 http://www.anicav.it/associazione/presentazione

32 The Guardian. The Terrible truth of about your tin of Italian tomatoes. October 2017 https://www.theguardian.com/global-development/2017/oct/24/the-terrible-truth-aboutyour-tin-of-italian-tomatoes

33 Federazione Lavoratori Agrolndustria - Confederazione Generale Italiana del Lavoro FLAI-CGIL. Observatory Placido Rizzotto. (2016). III Rapporto Agromafie e Caporalato. Op. cit.

34 \#FilieraSporca. (2016). Spolpati. La crisi dell'industria del Pomodoro. Tra sfruttamento e insostenibilità. Op. cit. 
35 Law no. 199/29 October 2016.

36 Gazzetta Ufficiale della Repubblica Italiana, Law no. 199/29 October 2016.

Disposizioni in materia di contrasto ai fenomeni del lavoro nero, dello sfruttamento del

lavoro in agricoltura e di riallineamento retributivo nel settore agricolo.

http://www.gazzettaufficiale.it/eli/id/2016/11/3/16G00213/sg 
(c) Oxfam International June 2018

This case study was written by Giorgia Ceccarelli (Oxfam Italy) in collaboration with Fabio Ciconte (Terra! Onlus). Oxfam acknowledges the assistance of Elisa Bacciotti and Federica Corsi in its production.

For further information on the issues raised in this paper please email policy@oxfam.it

This publication is copyright but the text may be used free of charge for the purposes of advocacy, campaigning, education, and research, provided that the source is acknowledged in full. The copyright holder requests that all such use be registered with them for impact assessment purposes. For copying in any other circumstances, or for re-use in other publications, or for translation or adaptation, permission must be secured and a fee may be charged. Email policyandpractice@oxfam.org.uk

The information in this publication is correct at the time of going to press.

Published by Oxfam GB for Oxfam International under ISBN 978-1-78748-268-5 in June 2018. DOI: 10.21201/2018.2685

Oxfam GB, Oxfam House, John Smith Drive, Cowley, Oxford, OX4 2JY, UK.

\section{OXFAM}

Oxfam is an international confederation of 20 organizations networked together in more than 90 countries, as part of a global movement for change, to build a future free from the injustice of poverty. Please write to any of the agencies for further information, or visit www.oxfam.org. 